\title{
OCCURRENCE OF UREAPLASMA DIVERSUM IN THE GENITAL TRACT OF FEMALE BUFFALOES (BUBALUS BUBALIS)
}

\author{
(Ocorrência de Ureaplasma diversum no trato genital de bubalinas (Bubalus \\ bubalis))
}

\begin{abstract}
${ }^{1}$ Grasiene de Meneses Silva, ${ }^{1}$ Pollyanne Raysa Fernandes de Oliveira, ${ }^{1}$ Allison Alves de Macêdo, 'Larice Bruna Ferreira Soares", ${ }^{2}$ Jonas de Melo Borges, ${ }^{3}$ Sandra Batista dos Santos, ${ }^{1}$ Rinaldo Aparecido Mota, ${ }^{1}$ José Wilton Pinheiro Junior
\end{abstract}

\begin{abstract}
1Universidade Federal Rural de Pernambuco, UFRPE, Recife, PE, Brasil; ${ }^{2}$ Médico Veterinário Autônomo, Rua Oliveira Lima 573, Heliópolis, Garanhuns, PE, CEP 55295-520, Brasil; ${ }^{3}$ Faculdades Nova Esperança, Avenida Frei Galvão 12, Gramame, João Pessoa-PB, Brasil
\end{abstract}

*E-mail para correspondência: brunaa_soares@ hotmail.com

\begin{abstract}
We investigated the occurrence of Ureaplasma diversum in the genital tract of female buffaloes. A total of 292 vaginal swab samples of buffaloes of reproductive age from nine farms were analyzed. These were distributed in five cities of Pernambuco state, Brazil. DNA was detected using polymerase chain reaction (PCR) technique. The frequency of females positive for $U$. diversum was $2.05 \%(6 / 292)$. Concerning the farms, $22.22 \%(2 / 9)$ of the investigated properties had at least one positive animal. Samples positive on PCR were inoculated in specific media for culturing Ureaplasma spp. However, there was no growth of characteristic colonies. This study documents the occurrence of infection by microorganisms of the species Ureaplasma diversum in the reproductive tract of buffalo females in the state of Pernambuco, Brazil. Thus, epidemiological investigations must be carried out with the presence of this microorganism should be investigated to assess the role of this pathogen as a causative agent of vulvovaginitis and abortions considering that these occurrences may decrease reproductive rates and cause negative economic impact in buffalo farming.
\end{abstract}

Keywords: Epidemiology; mPCR; Buffalo production; Ureaplasma diversum.

RESUMO: Objetivou-se com este estudo pesquisar a ocorrência de Ureaplasma diversum no trato genital de fêmeas bubalinas. Foram analisadas 292 amostras de suabe vaginal procedentes de búfalas em idade reprodutiva de nove propriedades, distribuídas em cinco municípios do estado de Pernambuco, Brasil. Para a detecção do DNA utilizou-se a Reação em Cadeia da Polimerase (PCR). A ocorrência de fêmeas positivas para Ureaplasma diversum foi 2,05\% (6/292). Em relação ao número de propriedades com fêmeas positivas, constatou-se que $22,22 \%(2 / 9)$ das propriedades possuíam ao menos um animal positivo. As amostras positivas na PCR foram inoculadas em meio específico para Ureaplasma spp., mas não houve crescimento de colônias características. Este estudo documenta a ocorrência de infecção por microrganismos da espécie Ureaplasma diversum no trato reprodutivo de fêmeas bubalinas no estado de Pernambuco, Brasil. Desta forma, investigações epidemiológicas devem ser realizadas com o intuito de avaliar a sua participação nos casos de vulvovaginite, abortos e consequentemente diminuição dos índices reprodutivos e seus impactos econômicos nos rebanhos bubalinos.

Palavras-chave: Epidemiologia; mPCR; Produção de búfalos; Ureaplasma diversum. 


\section{INTRODUCTION}

In animal production reproductive diseases cause economic losses (Fareed et al., 2017). Studies with buffaloes have demonstrated the occurrence of congenital, genetic, and acquired reproductive conditions leading to consequences, such as retained placenta, estrus repetition, endometritis, placentitis, and abortions (AlKennany et al., 2010).

Among the acquired causes, infections are important due to the variety of microorganisms involved. Some diseases that occur in cattle have been described in buffaloes, such as those caused by Brucella spp., Leptospira spp. and Chlamydophila abortus (Greco et al., 2007). Although Ureaplasma diversum may cause an impact in the reproductive cattle industry, few studies have investigated this pathogen in buffaloes. On the contrary, in cattle, there are more reports of infections by other members of the Mycoplasmataceae family, such as Mycoplasma bovigenitalium (Marouf et al., 2011) and M. bovis (Kaur et al., 2015).

The first report of $U$. diversum causing reproductive conditions in females in Brazil was described by Cardoso et al. (1997) who isolated the pathogen from vaginal mucous samples of cows with vulvovaginitis. In addition, other cases of vulvovaginitis, embryo death, and abortions related to this pathogen were described in cattle herds of the Paraíba (Santos et al., 2013) and Pernambuco (Santos et al., 2015; Macêdo et al., 2018). Considering the losses caused by U. diversum and the lack of studies on the presence of this pathogen in buffalo herds, we investigated the occurrence of $U$. diversum in the reproductive tract of female buffaloes.

\section{MATERIAL AND METHODS}

A convenience nonprobability sampling was performed at nine farms distributed in five cities in Mata and Agreste regions of Pernambuco state: Água Preta $(n=2)$, Maraial $(n=1)$, Rio Formoso $(n=1)$, Ribeirão $(n=4)$, and Agrestina $(n$ $=1$ ). The main buffalo farms in Pernambuco state are concentrated in these regions. This distribution is due to geographical characteristics and productive that this animal production requires.

A population of 10,000 buffaloes was considered (Instituto Brasileiro de Geografia e Estatística [IBGE], 2015) with an expected prevalence of $21.69 \%$ U. diversum (Macêdo et al., 2017) for elaborating the sampling methodology. Hence, a minimum of 262 samples $(n)$ were established, which guaranteed a confidence interval of $95 \%$ and statistical error of 5\%. From March 2016 to April 2017, a total of 292 vaginal swab samples were collected from buffaloes of reproductive age without clinical signs or history of reproductive conditions. For collection, each female was restrained and the vulva was prepared for the procedure. The area was washed with water and soap, dried with paper towels, and disinfected with alcohol $\left(70^{\circ} \mathrm{GL}\right)$. Subsequently, sterile swabs were rubbed in the internal walls of the vagina to collect the secretion. Samples were placed in sterile tubes containing $3 \mathrm{~mL}$ phosphate buffered saline $(\mathrm{pH}$ 7.2). Tubes were maintained in isothermal boxes with recycled ice and sent to the laboratory for processing.

In the laboratory, samples were divided in aliquots of $600 \mu \mathrm{L}$ for DNA extraction. This step was performed with the commercial kit Promega ${ }^{\circledR}$ (catalog number A1125; Promega Corporation, Madison, WI, USA) following the manufacturer's protocol. For culture and isolation, aliquots of $500 \mu \mathrm{L}$ were maintained in micro tubes containing glycerol in a 2:1 ratio. These were homogenized in vortex and stored in a $-20^{\circ} \mathrm{C}$ freezer until the procedure. Following DNA extraction, samples were submitted to multiplex PCR (mPCR) for detection of $U$. diversum. The target 
region was 16S rRNA and the following primer sequences were used: GTTTGATCCTGGCTCAGGAT and CTCATAAGCGAGCCGACATT. Thermal profile $\left(95^{\circ} 5^{\prime}, 94^{\circ} 1^{\prime}, 52^{\circ} 1^{\prime}\right.$ and $\left.72^{\circ} 2^{\prime}, 72^{\circ} 5^{\prime}, 4^{\circ} 5^{\prime}\right)$ of these sequences was adapted from that described by Tramuta et al. (2011). For each reaction, a mix of $15 \mu \mathrm{L}$ comprising 5 $\mu \mathrm{L}$ DNA, $0.5 \mu \mathrm{L}$ of each primer at $20 \mathrm{pm}, 6.25 \mu \mathrm{L}$ of GoTaq ${ }^{\circledR}$ GreenMaster Mix (Ref. M7122; Promega Corporation), and $2.75 \mu \mathrm{L}$ ultra-pure water was used and a previously sequenced sample of $U$. diversum was used as positive control. Ultra-pure water was used as negative control. Amplified products were submitted for electrophoresis (100 V/60 $\mathrm{min}$ ) in $2 \%$ agarose gel. In this step, $7 \mu \mathrm{L}$ of the PCR reaction was used with $0.5 \mu \mathrm{L}$ blue-green dye and $0.5 \mu \mathrm{L}$ buffer solution. A 100 base pairs molecular marker was used. Detection was performed with ultraviolet light and the result was photo documented. Products positive for $U$. diversum presented amplicons of 831 base pairs. DNA samples obtained during PCR were purified using Mega Quick-spin ${ }^{\mathrm{TM}}$ Total Fragment DNA purification kits (Intron Biotechnology, Kyungki-Do, Korea). Purified products were submitted to bidirectional sequencing using BigDye Terminator v.3.1 Cycle Sequencing Kits (Applied Biosystems, Foster City, CA, USA) following the manufacturer's instructions in an automatic sequencer ABI-PRISM 3130 (Applied Biosystems).

Positive samples in PCR were submitted to isolation and identification. Positive aliquots previously stored in glycerol were defrosted and inoculated in UB broth and agar for Ureaplasma spp. Isolation (Razin e Tully, 1996). All plates and tubes were incubated at $37^{\circ} \mathrm{C}$ under microaerophilic conditions for up to 21 days. Plates were examined daily with a stereoscopic microscope to identify colonies.

\section{RESULTS}

We found that $2.05 \%(6 / 292)$ of female buffaloes were infected with Ureaplasma diversum. Of six samples sent for sequencing, 50\% (3/6) were confirmed positive for $U$. diversum with a similarity of $94 \%-96 \%$. Considering the farms, $22.22 \%(2 / 9)$ of the investigated properties had at least one positive animal (Table 1). Positive samples were cultured in UB medium and monitored daily for 21 days. However, there was no growth of characteristic colonies.

Table 1 - Distribution of samples positive for Ureaplasma diversum in farms investigated with $\mathrm{MPCR}$ and culture.

\begin{tabular}{cccc}
\hline Farm & $\boldsymbol{N}^{*}$ & PCR (positive) & Isolation \\
\hline A & 5 & $3(50.0 \%)$ & Negative \\
B & 50 & - & $* *$ \\
C & 48 & - & $* *$ \\
D & 21 & - & $* *$ \\
E & 50 & - & Negative \\
F & 28 & $3(50.0 \%)$ & $* *$ \\
G & 25 & - & $* *$ \\
H & 41 & - & $* *$ \\
I & 24 & - &
\end{tabular}

${ }^{*}$ Number of samples collected from each farm.

${ }^{* \star}$ All samples were negative on PCR. 


\section{DISCUSSION}

This is the first study performed in Brazil reporting the occurrence of $U$. diversum in the reproductive system of female buffaloes. With this report, the presence of this pathogen in buffalo farms was demonstrated firsthand. The frequency of $U$. diversum in this study was $2.05 \%(6 / 292)$. Few studies have investigated the presence of this pathogen in buffaloes; therefore, a precise evaluation of its prevalence in buffalo populations is difficult. Onnureddy, Vengalrao e Mohanty (2013) reported a prevalence of $20.83 \%$ of infections by $U$. diversum in buffaloes with endometritis. On the contrary, they reported a prevalence of $3.63 \%$ in buffaloes that did not show reproductive conditions.

One factor that may explain the low frequency of $U$. diversum in this study is the absence of clinical signs in the investigated animals. During sampling, none of the animals showed clinical signs. In addition, farmers informed us that abortions were rare and, in these cases, the females were eliminated from the herd. This information is important, considering that studies with cattle indicate an association between the detection of the pathogen and the presence of suggestive clinical signs, such as vulvovaginitis, abortions, and estrus repetition.

Santos et al. $(2013,2015)$ investigated the presence of $U$. diversum in cows with estrus repetition in the states of Paraíba and Pernambuco, Brazil. They observed that the detection was associated with the presence of lesions in the vulvovaginal mucosa. In Brazil, Ribeiro, Mourão e Monteiro (2016) investigated the main pathologies found in buffaloes slaughtered in several cities of the Amapá state. Endometritis was one of the most common alterations found. However, the cause was not investigated further. The presence of reproductive infections caused by microorganisms of the Mollicutes class, such as U. diversum, are not notifiable diseases. Therefore, the test for the presence of $U$. diversum is not included as a routine examination for most countries. Therefore, information concerning the actual participation of these microorganisms in reproductive disorders is limited.

After infecting animals in a herd, $U$. diversum may cause reproductive disorders with slow evolution, especially in asymptomatic carriers. In this manner, farmers can notice only some alterations, such as low conception rates, when a high number of animals are infected. When animals are not frequently managed, lesions and secretions in the vaginal mucosa may be unidentified. In addition, these frequently are self-limiting, which may pass unnoticed. In most of the investigated farms, $66.66 \%(6 / 9)$, animals were reared in extensive systems and very few farms possessed squeeze chutes adequate for routine gynecological evaluations. In addition, the impact of $U$. diversum as a primary agent is difficult to assess due to the presence of other infectious diseases that cause similar clinical signs.

Concerning the farms with positive animals, 22.22\% (2/9) had at least one infected individual. This occurrence may be related to the manner in which buffalo production is performed in Pernambuco state. This activity is limited in the state, where there are a small number of farms and most of the trade of buffaloes occurs with other states or among the few producers within the state. Frequently, this is performed without quarantines or tests for the main reproductive diseases.

In sequencing, $50 \%(3 / 6)$ of samples were confirmed as $U$. diversum with a similarity range of $94 \%-96 \%$. However, the remaining samples were not sequenced, possibly due to the low amount of DNA found naturally in the samples. In addition, contamination by other microorganisms may affect the identification, and failures may occur in the process of purification (Macêdo et al., 2018). There was no growth of characteristic colonies when samples positive on PCR were cultured in specific 
media. This result may be due to the unviability of bacterial cells in samples during storage and reactivation. This limitation does not occur in PCR. In this method, the microorganism may be detected even when isolation is not viable, which provides better sensitivity (Cardoso et al., 1997).

Despite the difficulties in identifying this pathogen, this diagnostic should be encouraged and included in routine tests, especially at farms with reproductive issues in the cattle. Currently, more effective techniques may be performed to diagnose several species of Mollicutes (Parker et al., 2017). In addition, multiplex PCR may be used to detect several infectious agents with the advantages of reducing costs and providing early diagnostics (Kaur et al., 2015). Knowing the occurrence of reproductive problems in a given herd is essential to alert professionals on the importance of prevention and control of issues related to fertility/infertility. In addition, this knowledge is necessary for initiating adequate programs of reproductive management.

\section{CONCLUSION}

This study documents the occurrence of infection by microorganisms of the species Ureaplasma diversum in the reproductive tract of buffalo females in the state of Pernambuco, Brazil. Thus, epidemiological investigations must be carried out with the presence of this microorganism should be investigated to assess the role of this pathogen as a causative agent of vulvovaginitis and abortions considering that these occurrences may decrease reproductive rates and cause negative economic impact in buffalo farming.

\section{ACKNOWLEDGEMENTS}

The Federal Rural University of Pernambuco (UFRPE), the Laboratory of Infectious-Contagious Diseases of Domestic Animals (LIDIC / UFRPE) and the Foundation for Support to Science and Technology of Pernambuco (FACEPE), for their support in conducting this research.

\section{INFORMATIVE NOTES}

This study was approved by the Ethics Committee for the use of Animals of the Federal Rural University of Pernambuco with license number $n^{\circ}$ 043/2016.

\section{REFERENCES}

AL-KENNANY, E.R.; RAHAWY, M.A.; AL-ALLAF, E.S. Clinical and pathological study of retained placenta in Iraqi buffaloes. Journal of Veterinary Medical Science, v.9, n.1, p.96-11., 2010.

CARDOSO, M.V.; GRASSO, L.; STEFANO, E. et al. Isolation of Ureaplasma diversum and Mycoplasma spp. in bovine granular vulval cases. Brazilian Journal of Animal Reproduction, v.21, n.2, p.172-173, 1997.

FAREED, S.K.; MEMON, K.H.; KACHIWAL, A.B. et al. Prevalence and economic losses of reproductive disorders and mastitis in buffaloes at Karachi, Pakistan. Indian Journal of Animal Research, v.51, n.6, p.1130-1133, 2017.

GRECO, G.; D'ABRAMO, M.; CAMPANILE, G. et al. Reproductive disorders induced by Chlamydophila spp. Infections in an Italian mediterrane in buffalo (Bubalus bubalis) herd. Journal Animal Science, v.6, n.2, p.877-880, 2007.

INSTITUTO BRASILEIRO DE GEOGRAFIA E ESTATÍSTICA - IBGE. (2015). Produção 
em:<http://www.ibge.gov.br/home/estatistica/indicadoresagropecuario.pdf $>$.Acesso em: 15/10/2015.

KAUR, P.; SHARMA, N.S.; ARORA, A.K. Development of a multiplex PCR assay for detection of different bacterial pathogens associated with reproductive disorders in cattle and buffaloe. The Indian Journal of Animal Sciences, v.85, n.12, p.13061310, 2015.

MACÊDO, A.A.M.; OLIVEIRA, J.M.B.; SILVA, B.P. et al. Occurrence of Mycoplasma bovigenitalium and Ureaplasma diversum in dairy cattle from to Pernambuco state, Brazil. Brazilian Journal of Veterinary and Animal Science, v.70, n.6, p.17981806, 2018.

MAROUF, S.A.; MOHAMED, KH.F.; EL-JAKEE, J. Detection of Mycoplasma bovis and Mycoplasma bovinogenitalium in cattle and buffalo in Egypt using dot ELISA and PCR with Anti-Microbial Trials. European Journal of Biological Sciences, v.25, p.136-146, 2011.

ONNUREDDY, K.; VENGALRAO, Y.; MOHANTY, T.K. Metagenomic Analysis of Uterine Microbiota in Postpartum Normal and Endometritic Water Buffaloes (Bubalus bubalis). Journal of Buffalo Science, v.2, n.3, p.124-134, 2013.

PARKER, A.M.; HOUSE, J.K.; HAZELTON, M.S. et al. Comparison of culture and a multiplex probe PCR for identifying Mycoplasma species in bovine milk, semen and swab samples. Plos One, v.12, n.3, p.1-14, 2017.

RAZIN, S.; TULLY, J.G. (1996). Molecular and diagnostic procedures in Mycoplasmology. ed. 2. California: Academic Press, 1996. 483 p.

RIBEIRO, H.F.L.; MOURÃO, F.R.P.; MONTEIRO, F.J.C. et al. Diagnosis of investigative pathology in the genital tract of buffaloes raised extensively in the State of Amapá, Amazon, Brazil. Brazilian Journal of Veterinary Medicine, v.38, n.4, p.358-364, 2016.

SANTOS S.B.; PINHEIRO-JÚNIOR J.W.; OLIVEIRA A.A. et al. Occurrence of Mollicutes and Ureaplasma spp. in outbreak of reproductive disease in cattle herds, State of Paraíba, Brazil. Brazilian Journal of Veterinary Research, v.33, n.3, p.315-318, 2013.

SANTOS, S.B.; PINHEIRO-JÚNIOR, J.W.; MOTA, A.R. et al. Recovery of Mollicutes from the reproductive tract of dairy cattle in the state of Pernambuco, Brazil. Brazilian Journal of Veterinary Research, v.35, n.6, p.491-496, 2015.

TRAMUTA C.; LACERENZA D.; ZOPPI S. et al. Development of a set of multiplex standard polymerase chain reaction assays for the identification of infectious agents from aborted bovine clinical samples. Journal of Veterinary Diagnostic Investigation, v.23, n.4, 